Jurnal Akuntansi Bisnis, Vol. 19, No. 2, September 2021

ISSN 1412-775X (media cetak) | 2541-5204 (media online)

\title{
Analisis Pengaruh Likuiditas, Ukuran perusahaan, dan Konservatisme Akuntansi terhadap Kualitas Laba dengan Profitabilitas sebagai Variabel Moderasi \\ Olga Welly Charisma ${ }^{1 *}$, Dhini Suryandari² \\ ${ }^{1,2}$ Universitas Negeri Semarang \\ *Corresponding author email: wellyolga@ gmail.com
}

\begin{abstract}
The purpose of this study is to examine and analyze the effect of liquidity, firm size, and accounting conservatism on earnings quality by using profitability as a moderating variable. The population in this study are mining companies listed on the Indonesia Stock Exchange for the period 20172019. Using purposive sampling technique, as much 62 firm observations were gathered and used for the test of hypothesis. The analysis technique used is descriptive statistical analysis and inferential statistical analysis with moderated analysis regression interaction test as the moderating regression analysis. The results show that accounting conservatism has a positive effect on earnings quality. On the contrary, liquidity and firm size have no effect on earnings quality. In addition, profitability does not moderate the relationship between liquidity and earnings quality, profitability does not moderate the relationship between firm size and earnings quality, but profitability weakens the relationship between accounting conservatism and earnings quality.
\end{abstract}

Keywords: Liquidity, accounting conservatism, profitability, earnings quality.

\begin{abstract}
Abstrak
Tujuan dari penelitian ini untuk menguji dan menganalisis pengaruh likuiditas, ukuran perusahaan, dan konservatisme akuntansi terhadap kualitas laba dengan menggunakan profitabilitas sebagai variabel moderasi. Populasi dalam penelitian ini adalah perusahaan pertambangan yang terdaftar di Bursa Efek Indonesia periode 2017-2019. Teknik pengambilan sampel dengan menggunakan teknik purposive sampling menghasilkan 62 observasi perusahaan. Teknik analisis yang digunakan yaitu analisis statistik deskriptif dan analisis statistik inferensial dengan uji interaksi moderated analysis regression sebagai analisis regresi moderasinya. Teknik analisis data dengan menggunakan software IBM SPSS Statistics 24. Hasil pengujian hipotesis menunjukkan bahwa likuiditas tidak berpengaruh terhadap kualitas laba, ukuran perusahaan tidak berpengaruh terhadap kualitas laba, dan konservatisme akuntansi berpengaruh positif terhadap kualitas laba. Profitabilitas tidak memoderasi hubungan likuiditas terhadap kualitas laba, profitabilitas tidak memoderasi hubungan ukuran perusahaan terhadap kualitas laba, namun profitabilitas memperlemah hubungan konservatisme akuntansi terhadap kualitas laba.
\end{abstract}

Kata Kunci: Likuiditas, konservatisme akuntansi, profitabilitas, kualitas laba.

\section{PENDAHULUAN}

Laporan keuangan menjadi alat bagi manajemen perusahaan untuk memberikan informasi tentang perusahaan kepada para pengguna laporan keuangan (Wiryadi dan Sabrina, 2013). Laba yang diperoleh perusahaan merupakan salah satu faktor penting yang menjadi bahan pertimbangan 
Jurnal Akuntansi Bisnis, Vol. 19, No. 2, September 2021 ISSN 1412-775X (media cetak) | 2541-5204 (media online)

untuk pengambilan keputusan investor maupun kreditur. Tindakan perusahaan dalam melakukan manajemen laba dapat mengurangi kualitas laba yang dihasilkan oleh perusahaan. Laba yang berkualitas adalah laba yang tersaji dalam laporan keuangan sesuai dengan kondisi sesungguhnya pada perusahaan tersebut. Perusahaan dengan kualitas laba yang baik dapat menghasilkan laba secara berkelanjutan dan konsisten dalam setiap periodenya (Risdawaty dan Subowo, 2015). Kualitas laba yang baik berasal dari aktivitas operasional perusahaan bukan dari tindakan manajemen yang memperindah laporan keuangan.

Laba berjalan yang tidak memenuhi target rawan terhadap tindakan manipulasi laporan keuangan. Tindakan yang dapat merugikan pengguna laporan keuangan dapat dilihat dari beberapa kasus perusahaan yang melakukan manipulasi laporan keuangan. Dilansir dari situs Kontan.id (2020) perusahaan PT Timah (TINS) pada tahun 2018 melakukan pencatatan yang overstatement pada laporan keuangannya. Laba bersih yang seharusnya sebesar Rp 132,29 miliar, tetapi manajemen PT Timah mencatatkan laba bersih sebesar Rp 531,35 miliar. Temuan itu ditemukan setelah beberapa bulan setelah laporan keuangan PT Timah tahun 2018 dipublikasikan. Penyajian laporan keuangan PT Timah tahun 2018 yang overstatement terdapat pada beban pokok pendapatan, investasi properti, metode pengakuan pendapatan, pajak dibayar dimuka tidak tertagih, dan transaksi antar perusahaan. Kasus selanjutnya berasal dari laman beritalima.com (2016) PT Cakra Mineral telah melakukan tindakan yang tidak benar dengan mengklaim bahwa telah memiliki 55\% saham perusahaan Murui sejak bulan Agustus 2014, namun yang sebenarnya PT Cakra Mineral tidak pernah terdaftar sebagai pemegang saham Murui. Direksi PT Cakra (Boelio Muliadi) yang telah sengaja melakukan klaim atas kepemilikan saham perusahaan Murui mengakibatkan nilai aset PT Cakra Mineral Tbk menggelembung secara signifikan. Berdasarkan pada kedua kasus yang telah dipaparkan diatas menunjukkan bahwa PT Timah dan PT Cakra Mineral telah melakukan manipulasi laporan keuangan.

Penelitian-penelitian sebelumnya telah melakukan pengujian terhadap kualitas laba. Beberapa faktor yang digunakan untuk menguji kualitas laba pada penelitian sebelumnya, diantaranya struktur modal, pertumbuhan, investment opportunity set, leverage, kualitas audit, komite audit, kepemilikan institusional, likuiditas, ukuran perusahaan, kepemilikan manajerial, umur perusahaan, dewan komisaris, dewan direksi, komisaris independen, konservatisme akuntansi, profitabilitas, komite independen, harga saham, dan komite audit. Berdasarkan faktorfaktor pada penelitian sebelumnya, penulis tertarik untuk menguji pengaruh likuiditas, ukuran perusahaan, dan konservatisme terhadap kualitas laba dengan profitabilitas sebagai variabel moderasi.

Penelitian yang dilakukan oleh Salma dan Riska (2019) menunjukkan bahwa likuiditas tidak berpengaruh terhadap kualitas laba. Hasil penelitian tersebut didukung oleh penelitian Wijaya (2020), Rahmania (2019), dan Kurniawan dan Khafid (2017) yang juga menyatakan bahwa likuiditas tidak berpengaruh terhadap kualitas laba. Sementara itu, penelitian dari Marpaung (2019) menerangkan bahwa likuiditas berpengaruh negatif terhadap kualitas laba. Kemudian, Penelitian dari Silfi (2016), Safitri dan Mayar (2020), dan Gombola et al. (2016) mengungkapkan bahwa likuiditas berpengaruh positif terhadap kualitas laba perusahaan.

Penelitian Marpaung (2019) dan Laoli dan Herawaty (2019) menunjukkan bahwa ukuran perusahaan berpengaruh negatif terhadap kualitas laba. Sedangkan pada penelitian Wijaya (2020) menyatakan bahwa ukuran perusahaan berpengaruh positif terhadap kualitas laba. Hasil penelitian dari Wijaya (2020) didukung oleh Mojtahedi (2013) dan Kurniawan (2017) yang juga menyatakan bahwa ukuran perusahaan berpengaruh positif terhadap kualitas laba. Penelitian yang dilakukan Safitri dan Mayar (2020) dan Rahmania (2019) mengungkapkan bahwa ukuran perusahan tidak 
berpengaruh terhadap kualitas laba. Penelitian sebelumnya menggunakan konservatisme akuntansi untuk menguji pengaruhnya terhadap kualitas laba dapat ditunjukkan Kurniawan dan Nur (2020) memiliki pengaruh negatif terhadap kualitas laba. Selanjutnya, hasil penelitian dari Yunita dan Suprasto (2018), Safitri dan Mayar (2020), Tumpal Manik (2017), dan Ramadan (2015) mengungkapkan bahwa konservatisme akuntansi berpengaruh positif terhadap kualitas laba.

Hasil penelitian-penelitian sebelumnya yang tidak konsisten menjadi sebuah dorongan penulis untuk meneliti kembali variabel-variabel tersebut dengan menghadirkan profitabilitas sebagai variabel moderasi. Penelitian terdahulu yang menunjukkan profitabilitas sebagai variabel independen terhadap kualitas laba. Penelitian yang dilakukan oleh Salma dan Riska (2019) dan Rahmania (2019) menunjukkan bahwa profitabilitas memiliki pengaruh positif terhadap kualitas laba. Sedangkan penelitian yang dilakukan Ma (2017) dan Laoli dan Herawaty (2019) menemukan bahwa profitabilitas berpengaruh negatif terhadap kualitas laba.

Penelitian ini bertujuan untuk mengetahui dan menganalisis bukti empiris pengaruh likuiditas, ukuran perusahaan, dan konservatisme akuntansi terhadap kualitas laba, serta untuk membuktikan apakah profitabilitas dapat memoderasi hubungan antara likuiditas, ukuran perusahaan, dan konservatisme akuntansi terhadap kualitas laba. Orisinilitas dalam penelitian ini adalah adanya profitabilitas sebagai variabel moderasi, objek penelitian yang menggunakan perusahaan pertambangan yang terdaftar di Bursa Efek Indonesia, dan tahun pengamatan dari 2017-2019.

\section{LANDASAN TEORI DAN PERUMUSAN HIPOTESIS}

Teori keagenan menjelaskan hubungan keagenan merupakan suatu kontrak yang terjadi antara satu orang atau lebih (principal) melibatkan orang lain (agent) untuk melakukan suatu jasa atas nama prinsipal dengan memberikan wewenang kepada agen untuk membuat keputusan terbaik bagi prinsipal (Jensen dan Meckling, 1976). Di dalam suatu perusahaan ada pihak-pihak yang memiliki tujuan dan target masing-masing, hal tersebut berpeluang terjadinya konflik didalam perusahaan. Adanya teori keagenan memberikan solusi untuk meminimalisir terjadinya konflik akibat dari perbedaan kepentingan antara principal dan agent. Hubungan keagenan memberikan titik tengah antara masing-masing pihak yang memiliki tujuan dan target masing-masing dengan tidak saling merugikan pihak-pihak yang terlibat.

Teori ini menjelaskan hubungan antara manajemen sebagai pemberi sinyal dan pihak lain (investor) sebagai penerima sinyal. Spence (1973) mengatakan bahwa manajemen memberikan sebuah sinyal berupa informasi yang berkaitan dengan kondisi perusahaan kepada pihak investor, selanjutnya investor akan menimbang atas informasi yang disampaikan oleh pihak manajemen untuk pengambilan keputusan. Pihak investor akan menyesuaikan dengan informasi perusahaan yang diberikan oleh pihak manajemen. Sinyal yang dikeluarkan oleh manajemen berupa informasi mengenai kinerja perusahaan dalam meningkatkan kualitas dan nilai perusahaan (Lestari, 2017). Goodnews bagi sebuah perusahaan berupa kinerja perusahaannya memuaskan yang terdapat pada laporan tahunan, pihak investor akan lebih tertarik pada perusahaan yang berkinerja baik dan memiliki prospek ke depannya.

\section{Likuiditas dan Kualitas Laba}

Likuiditas merupakan rasio yang menggambarkan kemampuan perusahaan dalam memenuhi utang jangka pendek, apabila pihak kreditur menagih utang perusahaan, perusahaan dapat memenuhi utang tersebut terutama utang yang mendekati jatuh tempo (Kasmir, 2017). Likuiditas suatu perusahaan dapat menggambarkan bagaimana perputaran arus kas yang ada di 
Jurnal Akuntansi Bisnis, Vol. 19, No. 2, September 2021 ISSN 1412-775X (media cetak) | 2541-5204 (media online)

perusahaan tersebut dalam menggunakan kas untuk memenuhi utang perusahaan. Perusahaan yang dapat memenuhi utang jangka pendeknya sebelum jatuh tempo, menunjukkan bahwa perusahaan tersebut memiliki pengelolaan keuangan yang baik. Perusahaaan yang mampu memenuhi utang jangka pendeknya dapat disimpulkan bahwa perusahaan tersebut likuid. Tingkat likuiditas yang tinggi oleh perusahaan akan menunjukkan bahwa perusahaan tersebut dapat mengembalikkan dana yang dihimpun dari pihak ketiga. Kondisi tersebut dapat membangun citra positif perusahaan dari pihak ketiga untuk menanamkan atau meminjamkan dananya kepada perusahaan tersebut. Penelitian yang dilakukan Marpaung (2019) yang meniliti pengaruh leverage, likuiditas, dan ukuran perusahaan sebagai variabel moderasi terhadap kualitas laba dan hasilnya likuiditas berpengaruh negatif terhadap kualitas laba. Penelitian selanjutnya, Silfi (2016) menunjukkan likuiditas berpengaruh positif terhadap kualitas laba. Dengan demikian, hubungan likuiditas dan kualitas laba dapat dinyatakan dalam hipotesis berikut:

\section{H1: Likuiditas berpengaruh positif terhadap kualitas laba}

\section{Ukuran Perusahaan dan Kualitas Laba}

Ukuran perusahaan digunakan untuk menentukan skala atau penggolongan sebuah perusahaan. Perusahaan-perusahaan yang ada dibagi menjadi tiga skala, yaitu perusahaan kecil, perusahaan menengah, juga perusahaan besar. Penggolongan perusahaan berdasarkan total aset, total penjualan, total pendapatan yang dimiliki oleh setiap perusahaan. Ukuran perusahanan berdasarkan total aset, semakin besar total aset yang dimiliki perusahaan maka semakin besar pula ukuran perusahaan tersebut. Perusahaan yang termasuk ke dalam perusahaan besar memiliki total aset yang lebih besar dibanding dengan perusahaan yang berskala kecil maupun menengah, perusahaan besar cenderung menghasilkan laba yang stabil dan berkelanjutan. Total aset perusahaan yang besar diharapkan mampu menghasilkan laba yang tinggi untuk menghindari terjadinya konflik keagenan.

Wijaya (2020) meneliti pengaruh likuiditas, struktur modal, ukuran perusahaan, prospek pertumbuhan, kualitas audit terhadap kualitas laba pada perusahaan pertambangan di Bursa Efek Indonesia tahun 2012-2016. Hasil penelitian menunjukkan bahwa ukuran perusahaan berpengaruh positif terhadap kualitas laba. Semakin besar ukurana perusahaan maka discretionary accruals akan semakin kecil, discretionary accruals yang kecil menunjukkan kualitas laba yang tinggi (Wijaya, 2020). Penelitian lain, Kurniawan (2017) meniliti pengaruh ukuran perusahaan terhadap kualitas laba pada perusahaan perbankan yang terdaftar dalam Bursa Efek Indonesia tahun 20122014. Penelitiannya menunjukkan bahwa ukuran perusahaan memiliki pengaruh terhadap kualitas laba pada perusahaan perbankan. Dengan demikian, hubungan likuiditas dan kualitas laba dapat dinyatakan dalam hipotesis berikut:

\section{H2: Ukuran perusahaan berpengaruh positif terhadap kualitas laba}

\section{Konservatisme akuntansi dan Kualitas Laba}

Konservatisme akuntansi merupakan suatu penerapan sifat kehati-hatian perusahaan terhadap pengukuran aset dan laba karena ketidakpastian atas aktivitas perusahaan yang dapat dilihat dalam penyusunan laporan keuangan perusahaan, sehingga nantinya laporan keuangan perusahaan dapat bermanfaat bagi pengguna laporan keuangan (Lestari, 2017). Sifat kehati-hatian yang diterapkan yaitu tidak melaporkan aset secara overvalue dan tidak melaporkan utang secara undervalue ketika seorang akuntan melakukan penilaian terhadap aset dan utang perusahaan.

Prinsip konservatisme akuntansi juga digunakan untuk menghindari tindakan manajer dalam menyajikan laba secara berlebihan dalam laporan keuangan yang bertujuan untuk menarik para 
investor. Konservatisme akuntansi dapat bermanfaat untuk menghindari terjadinya konflik kepentingan antara principal dan agent. Sikap konservatif yang dilakukan manajemen dapat menghindari pembagian deviden yang berlebih kepada pihak investor, dilain sisi sikap konservatif juga dapat memberikan informasi laba yang berkualitas karena manajemen akan cenderung berhati-hati dalam mengelola perusahaan. Konservatisme memiliki dampak positif bagi kedua belah pihak jika saling mendahulukan kepentingan bersama diatas kepentingan pribadi. Penelitian yang dilakukan oleh Manik (2017) dan Safitri dan Mayar (2020) bahwa konservatisme akuntansi berpengaruh positif terhadap kualitas laba suatu perusahaan. Semakin tinggi tingkat konservatisme akuntansi yang diterapkan akan semakin berkualitas laba yang dihasilkan oleh perusahaan. Dengan demikian, hubungan likuiditas dan kualitas laba dapat dinyatakan dalam hipotesis berikut:

\section{H3: Konservatisme akuntansi berpengaruh positif terhadap kualitas laba}

\section{Profitabilitas, Likuiditas, dan Kualitas Laba}

Tingkat likuiditas perusahaan juga menjadi salah satu faktor penilaian pihak ketiga, bagaimana sebuah perusahaan mengelola aset yang dimilikinya. Perusahaan yang memiliki tingkat likuiditas yang tinggi mencerminkan bahwa perusahaan tersebut baik dalam mengelola asetnya. Profitabilitas perusahaan menunjukkan apakah suatu perusahaan dalam kondisi keuangan yang baik atau tidak. Profitabilitas juga dapat digunakan dalam menilai kinerja manajer didalam sebuah perusahaan. Perusahaan yang baik adalah perusahaan yang untung dalam menjalankan operasional perusahaan. Profitabilitas yang tinggi dalam sebuah perusahaan akan membantu perusahaan dalam memenuhi kewajiban melalui aset lanar perusahaan, karena aset lancar perusahaan mudah untuk dipergunakan. Silfi (2016) mengungkapkan bahwa semakin tinggi likuiditas berarti laba yang dihasilkan semakin berkualitas, sehingga manajemen perusahaan tidak perlu melakukan manajemen laba. (2019) menyatakan bahwa profitabilitas berpengaruh positif terhadap kualitas laba, hal tersebut dikarenakan semakin tinggi profitabilitas maka laba yang dihasilkan semakin berkualitas dan profitabilitas yang rendah akan memiliki citra perusahaan yang kurang baik.

\section{H4: Profitabilitas memperkuat hubungan antara likuiditas terhadap kualitas laba}

\section{Profitabilitas, Ukuran Perusahaan dan Kualitas Laba}

Semakin besar ukuran suatu perusahaan, maka perusahaan tersebut cenderung dapat menghasilkan laba yang stabil dan optimal. Perusahaan besar dalam mengelola perusahaannya cenderung lebih baik dibanding dengan perusahaan menengah maupun kecil. Kemampuan perusahaan besar dalam urusan teknis dan non-teknis didukung dari sumber daya yang dimiliknya, sumber daya yang lebih baik dan memadai. Rasio profitabilitas digunakan untuk mengukur komponen-komponen yang ada di laporan keuangan, terutama laporan posisi keuangan dan laporan laba rugi perusahaan. Ukuran perusahaan yang besar akan membuat laba yang dihasilkan juga lebih besar dibandingkan dengan perusahaan kecil maupun sedang, disisi lain laba perusahaan yang besar akan meningkatkan aset perusahaan. Laba perusahaan naik akan meningkatkan ukuran sebuah perusahaan. Perusahaan yang profitable tidak perlu melakukan manipulasi laba untuk menarik minat para investor menanamkan modalnya. Perusahaan dengan kondisi untung juga dapat meminimalisir terjadinya konflik keagenan, karena perusahaan dapat menghasilkan laba sesuai dengan harapan dari principal dan agent.

H5: Profitabilitas memperkuat hubungan antara ukuran perusahaan terhadap kualitas laba 
Jurnal Akuntansi Bisnis, Vol. 19, No. 2, September 2021 ISSN 1412-775X (media cetak) | 2541-5204 (media online)

\section{Profitabilitas, Konservatisme, dan Kualitas Laba}

Konservatisme akuntansi adalah konsep yang mengakui beban dan utang sesegera mungkin meskipun terdapat ketidakpastian pada akhirnya, kemudian mengakui pendapatan dan aset ketika sudah pasti diterima. Sikap kehati-hatian dalam pengukuran aset dan laba karena ketidakpastian selama kegiatan operasional perusahaan berlangsung. Konservatisme akuntansi dapat menghindari tindakan seorang manajer melakukan manipulasi laba secara berlebihan untuk membuat kinerja perusahaan sesuai dengan yang diinginkan seorang manajer. Perusahaan yang mendapatkan laba akan memberikan return kepada para investor yang menempatkan dananya pada perusahaan tersebut berupa deviden. Semakin tinggi laba suatu perusahaan akan menarik para investor untuk menanamkan modalnya kepada perusahaan tersebut, karena semakin besar pula deviden yang akan didapatkan nantinya. Perusahaan yang profitable akan memberikan rasa aman bagi investor didalamnya, sehingga para investor akan terus menanamkan modalnya kepada perusahaan yang profitable. Perusahaan yang profitable juga akan mendapat kemudahan dalam mencari dana dari pihak kreditur karena image perusahaan yang mampu menghasilkan laba. Profitabilitas perusahaan yang tinggi akan meningkatkan sikap konservatisme akuntansi untuk menghindari pembagian deviden yang berlebihan.

H6: Profitabilitas memperkuat hubungan antara konservatisme akuntansi terhadap kualitas laba

\section{METODE PENELITIAN}

\section{Populasi dan Sampel}

Populasi dalam penelitian ini yaitu seluruh perusahaan pertambangan yang terdaftar di Bursa Efek Indonesia (BEI) pada tahun 2017-2019. Pemilihan sampel dilakukan dengan menggunakan metode purposive sampling, yaitu pengambilan sampel dengan menetapkan kriteria-kriteria tertentu untuk memenuhi persyaratan dalam penelitian ini. Sampel merupakan bagian dari populasi yang dipercaya dapat merepresentasikan karakteristik populasi secara keseluruhan. Jumlah sampel yang memenuhi kriteria sebanyak 25 perusahaan sehingga selama tiga tahun periode penelitian terkumpul 75 observasi perusahaan seperti yang disajikan dalam Tabel 1.

Tabel 1. Kriteria Sampel Perusahaan

\begin{tabular}{|l|c|}
\hline \multicolumn{1}{|c|}{ Keterangan } & Jumlah \\
\hline $\begin{array}{l}\text { Perusahaan Pertambangan yang terdaftar di B`EI periode tahun 2017- } \\
\text { 2019. }\end{array}$ & 50 \\
\hline Perusahaan yang mengalami kerugian pada tahun 2017 -2019 & $(25)$ \\
\hline Jumlah sampel yang memenuhi kriteria & 25 \\
\hline
\end{tabular}

Sumber : Data sekunder yang diolah, 2021

\section{Definisi dan Pengukuran Variabel}

Kualitas laba berperan menjadi variabel dependen dalam penelitian ini. Likuiditas, ukuran perusahaan, dan konservatisme akuntansi sebagai variabel independen. Penelitian ini juga menghadirkan profitabilitas sebagai variabel moderasi.

Rincian mengenai pengertian variabel-variabel yang digunakan dalam penelitian ini dapat dilihat pada Tabel 2. 
Jurnal Akuntansi Bisnis, Vol. 19, No. 2, September 2021 ISSN 1412-775X (media cetak) | 2541-5204 (media online)

Tabel 2. Definisi dan Pengukuran Variabel

\begin{tabular}{|c|c|c|c|}
\hline Variabel & Definisi & Pengukuran & $\begin{array}{l}\text { Skala } \\
\text { Data }\end{array}$ \\
\hline $\begin{array}{l}\text { Kualitas } \\
\text { Laba (Y) }\end{array}$ & $\begin{array}{l}\text { Kualitas laba merupakan } \\
\text { kemampuan perusahaan } \\
\text { pada saat menyajikan laba } \\
\text { yang sebenarnya pada } \\
\text { perusahaan dan membantu } \\
\text { memprediksi laba di masa } \\
\text { yang akan datang dengan } \\
\text { mempertimbangkan } \\
\text { stabilitas dan persistensi } \\
\text { laba (Bellovary et al., } \\
\text { 2005). }\end{array}$ & $Q I R=\frac{\text { CFOit }}{\text { NIit }}$ & Rasio \\
\hline $\begin{array}{l}\text { Likuiditas } \\
\text { (X1) }\end{array}$ & $\begin{array}{l}\text { Likuiditas adalah } \\
\text { kemampuan suatu } \\
\text { perusahaan untuk } \\
\text { memenuhi utang jangka } \\
\text { pendeknya dengan aset } \\
\text { lancar yang dimiliki oleh } \\
\text { perusahaan tersebut (Silfi, } \\
\text { 2016). }\end{array}$ & $C R=\frac{\text { aset lancar }}{\text { kewajiban lancar }}$ & Rasio \\
\hline $\begin{array}{l}\text { Ukuran } \\
\text { Perusahaan } \\
\text { (X2) }\end{array}$ & $\begin{array}{l}\text { Ukuran perusahaan adalah } \\
\text { besar kecilnya suatu } \\
\text { perusahaan yang } \\
\text { ditunjukkan atau dinilai } \\
\text { oleh total aset, total } \\
\text { penjualan, laba yang } \\
\text { dihasilkan, beban pajak } \\
\text { dan lain-lain (Brigham \& } \\
\text { Houston, 2010). }\end{array}$ & Size $=$ Ln Total Asset & Rasio \\
\hline $\begin{array}{l}\text { Konserva- } \\
\text { tisme } \\
\text { Akuntansi } \\
\text { (X3) }\end{array}$ & $\begin{array}{l}\text { Konservatisme merupakan } \\
\text { konsep yang mengakui } \\
\text { beban dan utang sesegera } \\
\text { mungkin walaupun ada } \\
\text { ketidakpastian tentang } \\
\text { hasil akhirnya, namun } \\
\text { hanya mengakui } \\
\text { pendapatan dan aset ketika } \\
\text { sudah yakin akan diterima } \\
\text { (Savitri, 2016). }\end{array}$ & Cit $=\frac{(\text { NIit }- \text { CFit })}{\text { Aset }} x-1$ & Rasio \\
\hline $\begin{array}{l}\text { Profitabi- } \\
\text { litas }(\mathrm{Z})\end{array}$ & $\begin{array}{l}\text { Profitabilitas merupakan } \\
\text { sebuah analisis yang } \\
\text { dilakukan untuk } \\
\text { mengetahui seberapa besar }\end{array}$ & & Rasio \\
\hline
\end{tabular}


Jurnal Akuntansi Bisnis, Vol. 19, No. 2, September 2021

ISSN 1412-775X (media cetak) | 2541-5204 (media online)

\begin{tabular}{|l|l|l|}
\hline & $\begin{array}{l}\text { perusahaan mampu } \\
\text { menghasilkan laba dalam } \\
\text { satu periode } \\
\text { (Brigham \& Houston, } \\
\text { 2010). }\end{array}$ & $\begin{array}{l}\text { ROA } \\
\text { Earning after tax }\end{array} \times 100 \%$ \\
total asset & & \\
\hline
\end{tabular}

\section{Statistik Deskriptif}

Analisis statistik deskriptif digunakan untuk memberikan gambaran atau penjelasan atas suatu data yang dilihat dari nilai rata-rata (mean), standar deviasi, nilai minimum, dan nilai maksimum dari setiap variabel dalam penelitian ini. Penelitian ini menggunakan variabel independen, variabel dependen, dan variabel moderasi. Variabel independen dalam penelitian ini yaitu likuiditas, ukuran perusahaan, dan konservatisme akuntansi. Variabel dependen yang digunakan adalah kualitas laba (QIR). Sedangkan untuk variabel moderasi yaitu profitabilitas yang diproksikan dengan return on asset (ROA). Perlu disampaikan bahwa dari 75 observasi perusahaan yang terkumpul, sebanyak 13 harus dikeluarkan untuk memenuhi asumsi klasik. Tabel 3 menyajikan statistik deskriptif variabel-variabel yang digunakan dalam penelitian ini.

Tabel 3. Hasil Uji Statistik Deskriptif

\begin{tabular}{|l|r|r|r|r|r|}
\hline & $\mathrm{N}$ & Minimum & Maximum & Mean & Std. Deviation \\
\hline QIR & 62 & $-1,54$ & 2,30 &, 8140 &, 64825 \\
\hline LIKUID & 62 &, 21 & 4,56 & 1,6660 &, 92730 \\
\hline SIZE & 62 & 27,38 & 32,26 & 29,6197 & 1,25542 \\
\hline KONSER & 62 &,- 26 &, 25 &, 0652 &, 09396 \\
\hline ROA & 62 &, 00 &, 29 &, 0837 &, 06919 \\
\hline
\end{tabular}

Sumber : Data sekunder yang diolah, 2021

Berdasarkan Tabel 3 hasil uji statistik deskriptif menunjukkan bahwa dari 62 observasi penelitian, nilai standar deviasi dari variabel kualitas laba, likuiditas, ukuran perusahaan, dan profitabilitas lebih kecil dari nilai rata-rata setiap variabel itu sendiri. Nilai standar deviasi yang lebih kecil menunjukkan bahwa data bersifat homogen atau varians tidak terlalu besar. Nilai standar deviasi dari variabel konservatisme akuntansi yang lebih besar dari nilai rata-rata menunjukkan data bersifat heterogen atau menyebar.

\section{HASIL DAN PEMBAHASAN}

Analisis regresi berganda digunakan untuk menguji hipotesis dan hasilnya disajikan dalam Tabel 4. Dari tabel dapat dilihat bahwa hanya H3 yang diterima yang menunjukkan bahwa konservatisme mempengaruhi kualitas laba yang dilaporkan perusahaan.

\section{Pengaruh Likuiditas terhadap Kualitas Laba}

Hasil uji regresi atas pengaruh likuiditas terhadap kualitas laba menunjukkan nilai signifikansi sebesar 0,459 atau lebih besar dari 0,05 dengan nilai koefisien regresi sebesar 0,067. Berdasarkan penjelasan mengenai hasil tersebut dapat disimpulkan bahwa likuiditas tidak berpengaruh terhadap kualitas laba. Tingkat likuiditas sebuah perusahaan tidak memengaruhi 
Jurnal Akuntansi Bisnis, Vol. 19, No. 2, September 2021 ISSN 1412-775X (media cetak) | 2541-5204 (media online)

kualitas laba yang dihasilkan. Hal ini dikarenakan likuiditas tinggi yang dimiliki oleh perusahaan tidak menjamin bahwa manajemen perusahaan dapat mengelola perusahaan dengan baik, sehingga

Tabel 4. Ringkasan Hasil Uji Hipotesis

\begin{tabular}{|l|l|c|c|}
\hline \multicolumn{1}{|l|}{ Hipotesis } & Sig. $(<\mathbf{0 , 0 5})$ & Keputusan \\
\hline H1 & Likuiditas berpengaruh positif terhadap kualitas laba. & 0,378 & Ditolak \\
\hline H2 & Ukuran perusahaan berpengaruh positif terhadap kualitas & 0,634 & Ditolak \\
\hline H3 & $\begin{array}{l}\text { Konservatisme akuntansi berpengaruh positif } \\
\text { terhadap kualitas laba. }\end{array}$ & 0,000 & Diterima \\
\hline H4 & $\begin{array}{l}\text { Profitabilitas memperkuat hubungan antara likuiditas } \\
\text { terhadap kualitas laba }\end{array}$ & $\begin{array}{l}\text { Profitabilitas mampu memperkuat hubungan antara } \\
\text { ukuran perusahaan terhadap kualitas laba }\end{array}$ & Ditolak \\
\hline H6 & $\begin{array}{l}\text { Profitabilitas mampu memperkuat hubungan antara } \\
\text { konservatisme akuntansi terhadap kualitas laba }\end{array}$ & 0,029 & Ditolak \\
\hline
\end{tabular}

Sumber : Data sekunder yang diolah, 2021

kualitas laba yang dihasilkan baik. Semakin tinggi likuiditas sebuah perusahaan, akan semakin mudah perusahaan tersebut memperoleh pendanaan dari pihak ketiga. Sehingga manajemen akan terus berupaya untuk mempertahankan tingkat likuiditas perusahaan yang tinggi daripada kinerja perusahaan yang baik, hal ini akan mengganggu operasional perusahaan. Apabila likuiditas perusahaan terlalu besar maka perusahaan akan sulit mengelola aset lancarnya semaksimal mungkin, hal ini akan berdampak pada kinerja perusahaan yang kurang baik sehingga besar kemungkinan perusahaan tersebut melakukan manajemen laba. Hasil pada penelitian ini mematahkan teori sinyal atas likuiditas perusahaan.

Hasil penelitian ini memperkuat penelitian yang dilakukan oleh Kurniawan (2017), Priyandani (2020) dan Salma (2019) yang menyatakan bahwa likuiditas tidak berpengaruh terhadap kualitas laba. Tingkat likuiditas sebuah perusahaan tidak menjamin bahwa perusahaan tersebut menghasilkan laba yang berkualitas.

\section{Pengaruh Ukuran Perusahaan terhadap Kualitas Laba}

Hasil uji regresi atas pengaruh ukuran perusahaan terhadap kualitas laba menunjukkan bahwa ukuran perusahaan yang diukur melalui pendekatan log of total asset memiliki nilai signifikansi sebesar 0,172 atau lebih besar dari 0,05. Nilai koefisien regresi dari variabel ukuran perusahaan yaitu sebesar 0,091. Berdasarkan penjelasan atas hasil tersebut dapat disimpulkan bahwa ukuran perusahaan tidak berpengaruh terhadap kualitas laba. Perusahaan yang memiliki total aset besar dan termasuk perusahaan dengan ukuran yang besar tidak menjamin bahwa perusahaan tersebut mampu menghasilkan laba yang besar. Perusahaan besar dalam menghasilkan laba juga memiliki tingkat risiko yang sebanding, potensi risiko yang cenderung besar juga. Tingginya risiko yang dihadapi oleh sebuah perusahaan besar tentu akan memengaruhi perusahaan 
tersebut langsung maupun tidak langsung. Semakin tinggi risiko sebuah perusahaan akan mendorong pihak manajemen untuk melakukan manajemen laba, hal itu akan berdampak terhadap kualitas laba perusahaan. Hal ini mematahkan teori keagenan atas ukuran perusahaan.

Hasil penelitian yang menunjukkan bahwa ukuran perusahaan tidak berpengaruh terhadap kualitas laba perusahaan mematahkan teori keagenan dimana perusahaan dengan ukuran yang besar akan menghasilkan laba yang tinggi. Hasil penelitian ini mendukung penelitian yang dilakukan Rahmania (2019) dan Safitri (2020) yang menyatakan bahwa ukuran perusahaan tidak berpengaruh terhadap kualitas laba. Walaupun perusahaan memiliki aset yang besar dan memiliki sumber daya yang besar belum tentu perusahaan tersebut memiliki kualitas laba yang baik. Perusahaan yang besar dapat menghasilkan laba yang besar tetapi terdapat juga risiko besar yang harus dihadapi, risiko yang bisa datang kapan saja.

\section{Pengaruh Konservatisme Akuntansi terhadap Kualitas Laba}

Hasil uji regresi atas pengaruh konservatisme akuntansi terhadap kualitas laba menunjukkan nilai signifikansi 0,000 atau kurang dari 0,05 dengan nilai koefisien regresi sebesar 6,975 . Nilai koefisien regresi yang positif menunjukkan bahwa terdapat hubungan satu arah antara konservatisme akuntansi dengan kualitas laba. Berdasarkan penjelasan mengenai hasil tersebut dapat disimpulkan bahwa konservatisme berpengaruh positif terhadap kualitas laba. Prinsip konservatisme akuntansi berpengaruh positif terhadap kualitas laba sebuah perusahaan. Semakin tinggi prinsip konservatif yang diterapkan semakin berkualitas laba yang dihasilkan oleh sebuah perusahaan. Konservatisme akuntansi mengurangi terjadinya pengakuan laba yang berlebihan. Tindakan manajemen untuk melakukan manajemen laba untuk mempercantik laporan keuangan perusahaan juga dapat dihindari. Jika penerapan sikap konservatisme akuntansi yang rendah dapat membuat tindakan memanipulasi laba rentan terjadi, sehingga akan mengurangi kualitas laba perusahaan.

Berdasarkan temuan ini akan mengonfirmasi teori keagenan, dengan adanya konservatisme akuntansi dapat melindungi pihak principal dari tindakan dari manajemen perusahaan untuk memanipulasi laporan keuangan. Sehingga pihak manajemen mempunyai batasan agar tidak bertindak yang bisa merugikan pihak lainnya, manajemen sebagai agent bekerja untuk pihak principal. Disisi lain, penerapan prinsip konservatisme akuntansi dapat menghindari pembagian deviden yang berlebihan kepada para investor. Prinsip konservatisme akuntansi memberikan dampak yang baik bagi pihak agent dan principal, dengan dampak positif tersebut akan mengurangi konflik keagenan yang bisa terjadi didalam sebuah perusahaan karena keegoisan pada salah satu pihak.

Hasil penelitian ini sejalan dengan penelitian yang dilakukan Yunita (2018) dan Manik (2017) yang menyatakan bahwa konservatisme akuntansi berpengaruh positif terhadap kualitas laba. Sedangkan penelitian ini bertentangan dengan penelitian dari Kurniawan (2020) yang menyatakan konservatisme akuntansi berpengaruh negatif terhadap kualitas laba perusahaan.

\section{Pengaruh Profitabilitas Terhadap Hubungan antara Likuiditas dan Kualitas Laba}

Berdasarkan hasil uji regresi pada atas profitabilitas memoderasi pengaruh likuiditas terhadap kualitas laba menunjukkan nilai signifikansi sebesar 0,464. Nilai koefisien regresi sebesar $-0,771$. Nilai signifikansi yang lebih dari 0,05 menunjukkan bahwa interaksi variabel profitabilitas dengan likuiditas tidak berpengaruh terhadap kualitas laba. Berdasarkan hasil tersebut dapat diartikan bahwa profitabilitas tidak mampu memoderasi pengaruh likuiditas terhadap kualitas laba. Hasil pengujian ini secara empiris menyatakan bahwa profitabilitas tidak mampu memoderasi 
Jurnal Akuntansi Bisnis, Vol. 19, No. 2, September 2021 ISSN 1412-775X (media cetak) | 2541-5204 (media online)

pengaruh likuiditas terhadap kualitas laba. Semakin tinggi likuiditas sebuah perusahaan tidak selalu diikuti dengan kualitas laba yang tinggi pula. Likuiditas perusahaan yang tinggi belum tentu memiliki laba yang tinggi dan stabil. Tingkat likuiditas yang tinggi juga akan menimbulkan risiko yang juga lebih besar, sehingga akan menyebabkan operasional perusahaan terganggu. Profitabilitas perusahaan yang tinggi juga belum bisa dipastikan bahwa perusahaan tersebut bebas dari praktik manajemen laba. Tindakan mempercantik laba pada sebuah perusahaan sangat merugikan pihak ekternal yang menggunakan laporan keuangan sebagai bahan pengambilan keputusan.

Hasil penelitian ini mematahkan teori sinyal yang menjelaskan bahwa jika suatu perusahaan sedang berada pada kondisi yang baik, maka akan memberikan sinyal positif kepada pihak eksternal. Kondisi yang baik dalam hal ini perusahaan dengan keadaan profitable, sehingga akan memberikan dampak yang baik. Informasi yang dikeluarkan dari pihak manajemen agar para pihak eksternal dapat menilai dan memiliki pandangan terhadap perusahaan kedepannya. Perusahaaan yang baik memiliki laba yang tinggi akan tetapi laba yang dihasilkan belum tentu berkualitas. Perusahaan yang menghasilkan laba yang tinggi bisa jadi melakukan manajemen laba, sehingga akan menurunkan kualitas laba perusahaan.

\section{Pengaruh Profitabilitas Terhadap Hubungan Ukuran Perusahaan dan Kualitas Laba}

Hasil uji regresi dari interaksi profitabilitas dengan ukuran perusahaan terhadap kualitas laba menunjukkan nilai signifikansi sebesar 0,343. Nilai koefisien regresi sebesar 0,066. Nilai signifikansi yang lebih besar dari 0,05 berarti bahwa interaksi variabel profitabilitas dengan ukuran perusahaan tidak berpengaruh terhadap kualitas laba. Berdasarkan hasil tersebut, profitabilitas tidak mampu memoderasi pengaruh ukuran perusahaan terhadap kualitas laba. Ukuran perusahaan yang besar dan profitabilitas yang tinggi tidak menjamin bahwa kualitas laba yang dihasilkan oleh perusahaan dengan ciri-ciri tersebut dapat dikatakan baik. Kualitas laba perusahaan tidak bergantung pada besar kecilnya ukuran perusahaan yang dicerminkan dari jumlah aset perusahaan. Kualitas laba juga tidak bergantung pada profitabilitas pada perusahaan. Perusahaan yang ingin menghasilkan kualitas laba yang baik memiliki komitmen yang kuat sehingga tidak melakukan tindakan yang merugikan perusahaan.

Hasil penelitian ini mematahkan teori keagenan yang menyebutkan bahwa dengan profitabilitas yang tinggi tidak akan menimbulkan konflik keagenan karena target perusahaan yang sudah tercapai. Ukuran perusahaan yang besar cenderung akan memiliki profitabilitas yant tinggi karena memiliki sumber daya yang besar untuk kegiatan operasionalnya. Semakin bertambah besarnya laba yang didapatkan oleh perusahaan akan membuat perusahaan tersebut menjadi lebih besar, karena bertambahnya aset dan harta dalam perusahaan tersebut. Namun, berdasarkan hasil pengujian pada penelitian ini ukuran perusahaan yang besar tidak menjamin memiliki laba yang lebih besar dari ukuran perusahaan yang lebih kecil. Sehingga, tindakan manajemen laba tidak bergantung pada ukuran dan profitabilitas perusahaan.

\section{Pengaruh Profitabilitas Terhadap Hubungan Konservatisme dan Kualitas Laba}

Hasil uji regresi dari interaksi profitabilitas dengan konservatisme akuntansi terhadap kualitas laba menunjukkan nilai signifikansi sebesar 0,029 dan nilai koefisien regresi sebesar 23,170. Nilai signifikansi yang lebih besar dari 0,05 berarti interaksi variabel profitabilitas dengan konservatisme akuntansi berpengaruh negatif terhadap kualitas laba. Berdasarkan hasil tersebut, profitabilitas mampu memoderasi pengaruh konservatisme akuntansi terhadap kualitas laba. Namun arahnya tidak sesuai prediksi. Pengujian menunjukkan profitabilitas memperlemah 
Jurnal Akuntansi Bisnis, Vol. 19, No. 2, September 2021 ISSN 1412-775X (media cetak) | 2541-5204 (media online)

pengaruh konservatisme akuntansi terhadap kualitas laba. Adanya hubungan negatif antara profitabilitas dengan konservatisme akuntansi dalam penelitian ini mungkin disebabkan perusahaan tidak menggunakan prinsip akuntansi yang konservatif ketika perusahaan dapat menghasilkan laba yang tinggi. Hal tersebut dilakukan untuk menjaga nama baik bagi perusahaan dimata kreditur maupun investor. Akan tetapi,perusahaan akan menerapkan prinsip konservatisme ketika perusahaan dalam keadaan yang kurang baik dimana hanya menghasilkan laba yang rendah untuk mengantisipasi hal-hal yang dapat merugikan perusahaan dan menghindari tindakan manajemen laba.

Hasil penelitian ini mematahkan teori sinyal yang beranggapan ketika profitabilitas perusahaan yang tinggi menunjukkan laba perusahaan itu tinggi, dengan laba yang tinggi akan memberikan sinyal positif kepada pihak eksternal. Tingginya profitabilitas suatu perusahaan akan membuat manajemen perusahaan memilih metode akuntansi yang konservatif, karena konservatisme akuntansi dapat mengurangi terjadinya kesalahan dalam proses pelaporan keuangan. Namun, berdasarkan hasil pengujian interaksi profitabilitas dengan konservatisme akuntansi yang negatif. Profitabilitas perusahaan akan memengaruhi keputusan perusahaan dalam menerapkan prinsip konservatisme akuntansi.

\section{SIMPULAN}

Simpulan dalam penelitian ini adalah likuiditas tidak berpengaruh terhadap kualitas laba. Selanjutnya, ukuran perusahaan juga tidak berpengaruh terhadap kualitas laba. Sementara itu, konservatisme akuntansi berpengaruh positif terhadap kualitas laba. Profitabilitas sebagai variabel moderasi terbukti tidak mampu memoderasi pengaruh likuiditas dan ukuran perusahaan terhadap kualitas laba, namun profitabilitas mampu memoderasi dengan memperlemah pengaruh konservatisme akuntansi terhadap kualitas laba.

Saran bagi penelitian selanjutnya diharapkan menggunakan istilah prudence, karena istilah konservatisme akuntansi telah diperbaharui. Penelitian selanjutnya memperluas sampel penelitian dan menambahkan variabel-variabel lainnya yang memiliki pengaruh terhadap kualitas laba. Saran bagi perusahaan diharapkan agar menerapkan prinsip konservatisme akuntansi untuk menghasilkan kualitas laba yang lebih baik, karena dalam penelitian ini konservatisme akuntansi berpengaruh positif dalam meningkatkan kualitas laba perusahaan.

\section{DAFTAR PUSTAKA}

Bellovary, L, J., dan E, D. 2005. Earnings Quality: It's Time to Measure and Report. The CPA Journal, 75(11), 32-37.

Beritalima.com. 2016. No Title. Beritalima. https://beritalima.com/direksi-pt-cakra-mineral-tbkdilaporkan-bei-dan-ojk-2/

Brigham, E. F., dan Houston, J. F. 2010. Manajemen Keuangan Edisi Kedelapan. In Erlangga Jakarta, 3(3),

Gombola, M. J., Ho, A. Y. F., dan Huang, C. C. 2016. The effect of leverage and liquidity on earnings and capital management: Evidence from U.S. commercial banks. International 
Jurnal Akuntansi Bisnis, Vol. 19, No. 2, September 2021 ISSN 1412-775X (media cetak) | 2541-5204 (media online)

Review of Economics and Finance, 43, 35-58. https://doi.org/10.1016/j.iref.2015.10.030

Jensen, M. C., dan Meckling, W. H. 1976. Theory of the firm: Managerial behavior, agency costs and ownership structure. Journal of Financial Economics, 3(4), 305-360. https://doi.org/10.1016/0304-405X(76)90026-X

Kasmir. 2017. Analisis Laporan Keuangan. Edisi Kesatu. Cetakan Kedelapan. In PT Raja Grafindo Persada.

Kurniawan, A. R., dan Khafid, M. 2017. Factors Affecting The Quality Of Profit In Indonesia Banking Companies. Jurnal Dinamika Akuntansi, $8(1), \quad 30 \quad$ - 39. https://doi.org/10.15294/jda.v8i1.9117

Kurniawan, E., dan Nur, S. 2020. Pengaruh Set Kesempatan Investasi , Konservatisme dan Pertumbuhan Laba Terhadap Kualitas Laba Pada Perusahaan Manufaktur Di Indonesia. Jurnal Akuntansi dan Keuangan 2(1), 55-72.

Laoli, A. N., dan Herawaty, V. 2019. Pengaruh Profitabilitas, Growth, Leverage, Operating Cycle dan Prudence terhadap Kualitas Laba dengan Firm Size sebagai Variabel Moderasi. Prosiding Seminar Nasional Cendekiawan, $\quad 2000, \quad 2(1), \quad 89-95$. https://doi.org/10.25105/semnas.v0i0.5828

Lestari, W. D. 2017. Pengaruh Struktur Modal, Ukuran Perusahaan, Proporsi Dewan Komisaris, dan Kepemilikan Manajerial terhadap Kualitas Laba dengan Konservatisme Akuntansi sebagai Variabel Pemoderasi. Jurnal Sains Dan Seni ITS, 2(1), 3-10.

Ma, S., dan Ma, L. 2017. The association of earnings quality with corporate performance. Pacific Accounting Review, 29(3), 397-422. https://doi.org/10.1108/par-02-2016-0014

Marpaung, E. I. 2019. Pengaruh Leverage, Likuiditas dan Ukuran Perusahaan Sebagai Variabel Moderasi Terhadap Kualitas Laba. Journal of Accounting, Finance, Taxation, and Auditing (JAFTA), 1(1), 1-14. https://doi.org/10.28932/jafta.v1i1.1524

Mojtahedi, P. 2013. The Impact of Intellectual Capital on Earning Quality: Evidence from Malaysian Firms. Australian Journal of Basic and Applied Sciences, 7(2), 535-540.

Priyandani, A. 2020. Pengaruh Struktur Modal, Ukuran Perusahaan dan Likuiditas terhadap Kualitas Laba dengan Konservatisme Akuntansi sebagai Variabel Moderasi. Jurnal Dinamika Akuntansi, 12(1), 1-21.

Rahmania, K. 2019. Pengaruh Konvergensi IFRS, Profitabilitas, Likuiditas, Leverage dan Size terhadap Kualitas Laba. STIE Perbanas Surabaya. 3(2), 1-17. http://eprints.perbanas.ac.id/5037/

Ramadan, I. Z. 2015. Earnings Quality Determinants of the Jordanian Manufacturing Listed Companies. International Journal of Economics and Finance, 7(5), 140-146. https://doi.org/10.5539/ijef.v7n5p140

Risdawaty, iin mutmainah eka, dan Subowo. 2015. Pengaruh Struktur Modal, Ukuran Perusahaan, Asimetri Informasi, dan Profitabilitas terhadap Kualitas Laba. Jurnal Dinamika Akuntansi. $7(2), 109-118$. 
Jurnal Akuntansi Bisnis, Vol. 19, No. 2, September 2021 ISSN 1412-775X (media cetak) | 2541-5204 (media online)

Safitri, R., dan Mayar, A. 2020. Pengaruh Ukuran Perusahaan, Siklus Operasi, dan Konservatisme Akuntansi terhadap Kualitas Laba. Jurnal Eksplorasi Akuntansi, 2(4), 3793-3807.

Salma, N., dan Riska, T. J. 2019. Pengaruh Rasio Leverage, Likuiditas, Profitabilitas terhadap Kualitas Laba Perusahaan Makanan Minuman BEI. Competitive, 14(2), 84-95. https://doi.org/10.36618/competitive.v14i2.622

Savitri, E. 2016. Konservatisme Akuntansi: Cara Pengukuran, Tinjauan Empiris dan Faktor-Faktor yang Mempengaruhinya. Konservatisme Akuntansi: Cara Pengukuran, Tinjauan Empiris Dan Faktor-Faktor Yang Mempengaruhinya, 103.

Silfi, A. 2016. Pengaruh Pertumbuhan Laba, Struktur Modal, Likuiditas Dan Komite Audit Terhadap Kualitas Laba. Jurnal Valuta, 2(1), 17-26.

Spence, M. 1973. Job Market Signaling. Quarterly Journal of Economics. 1(1), 281-306. https://doi.org/10.2307/1882010

Suci, A. 2020. Timah (TINS) Merevisi Laporan Keuangan Tahun 2018, Ada Apa? Kontan.Co.Id. https://insight.kontan.co.id/news/timah-tins-merevisi-laporan-keuangan-tahun-2018-adaapa?page=all (diakses pada tanggal 5 mei 2021)

Tumpal, M. 2017. Praktik Konservatisme Akuntansi Melalui Mekanisme Corporate Governance terhadap Kualitas Laba. Jurnal Ilmiah Akuntansi Dan Finansial Indonesia, 1(1), 1-14. https://doi.org/10.31629/jiafi.v1i1.1234

Wijaya, C. F. 2020. Pengaruh Likuiditas, Struktur Modal, Ukuran Perusahaan, Prospek Pertumbuhan, Kualitas Audit terhadap Kualitas Laba Perusahaan Batu Bara. Jemap, 3(2), 206. https://doi.org/10.24167/jemap.v3i2.226

Wiryadi, A., dan Sabrina, N. (2013). Pengaruh Asimetri Informasi, Kualitas Audit, dan Struktur Kepemilikan terhadap Manajemen Laba. Wahana Riset Akuntansi, 1(2), 155-180.

Yunita, P. A., dan Suprasto, H. B. (2018). Pengaruh Konservatisme dan Investment Opportunity Set (IOS) terhadap Kualitas Laba dengan Kepemilikan Manajerial Sebagai Pemoderasi.EJurnal Akuntansi, 24(3), 1908-1937. https://doi.org/10.24843/eja.2018.v24.103.p10 